\title{
Kepribadian Ayub
}

\author{
Kalis Stevanus \\ Sekolah Tinggi Teologi Tawangmangu \\ kalisstevanus91@gmail.com
}

Abstract: Individual personality development is influenced by various factors, there are internal and external factors. This paper aims to determine whether a unique life experience, namely suffering, can influence the formation of a person's personality. This study uses a biblical study approach to the story of Job in the book of Ayub with a narrative interpretation method and also uses a literature study approach. It is evident that unpleasant life experiences such as the suffering that befell Job do not change Job's good personality. Job was a godly and honest man; fear Allah and shun evil; a person of sincerity or integrity; an optimist; a generous person; and a man who is loyal to his wife Keywords: Job, the Book of Job, Personality

\begin{abstract}
Abstrak: Perkembangan kepribadian individu dipengaruhi oleh berbagai faktor, ada faktor internal dan faktor eksternal. Tulisan ini bertujuan untuk mengetahui apakah pengalaman hidup yang unik, yakni penderitaan dapat memengaruhi pembentukan kepribadian seseorang. Penelitian ini menggunakan pendekatan kajian biblikal terhadap kisah Ayub di dalam kitab Ayub dengan metode tafsir naratif dan juga menggunakan pendekatan studi literatur. Terbukti bahwa pengalaman hidup yang tidak menyenangkan seperti penderitaan yang menimpa Ayub tidak merubah kepribadian Ayub yang baik. Ayub adalah seorang yang saleh dan jujur; takut akan Allah dan menjauhi kejahatan; seorang yang tulus atau berintegritas; seorang yang optimis; seorang yang murah hati; dan seorang yang setia pada istrinya. Kata Kunci: Ayub, Kitab Ayub, Kepribadian
\end{abstract}

Article History : $\quad$ Received: 27 September 2020 Revised: 30 Desember 2020 Accepted:30 Desember 2020

\section{Pendahuluan}

Secara etimologi, kata kepribadian berasal dari kata Yunani personare, ian berasal dari kata Yunani personare, yang berarti menyuarakan melalui alat. Pada zaman Yunani kuno, para pemaian sandiwara berdialog memakai penutup wajah atau topeng (persona). Dari kata persona atau topeng ini kemudian diterjemahkan ke dalam bahasa Inggris menjadi personality (kepribadian). ${ }^{1}$ Dalam perkembangan selanjutnya,

\footnotetext{
${ }^{1}$ Jalaludin, Teologi Pendidikan, (Jakarta: PT Raja Grafindo Persada, 2003), 191.
} 
kepribadian dipahami sebagai seluruh pemikiran, perasaan dan perilaku nyata yang disadari maupun yang tidak disadari. ${ }^{2}$ Hal yang senada dikemukakan oleh Koentjaningrat, bahwa kepribadian atau personality adalah sebagai perbedaan perilaku atau tindakan-tindakan dari tiap-tiap individu manusia. ${ }^{3}$ Dengan demikian, dapatlah disimpulkan bahwa kepribadian bukanlah tingkah laku, namun kepribadianlah yang membentuk tingkah seseorang, sehingga dapat diamati dari cara berpikir, berbicara, atau bertingkah laku.

Lebih tegas lagi dikatakan Daviq Chairilsyah, bahwa kepribadian bukanlah sesuatu yang statis sebab kepribadian memiliki sifat-sifat dinamis yang disebut dinamika kepribadian. Dinamika kepribadian ini berkembang pesat pada pasa kanakkanak karena pada dasarnya mereka masih memiliki pribadi yang belum matang, yakni masa pembentukan kepribadian. ${ }^{4}$ Dari uraian di atas, ditarik simpulan bahwa pada hakikatnya kepribadian meruoakan gambaran sikap dan tingkah laku individu yang terlihat dari ucapan dan perbuatannya. Selain itu, kepribadian memiliki sifat dinamis dari waktu ke waktu. Maksudnya, sikap dan tingkah laku dalam diri seseorang dapat berubah dan menyesuaikan diri terhadap segala stimulasi, baik yang muncul dari dalam dirinya maupun di luar dirinya.

Secara umum, terdapat dua (2) faktor yang memengaruhi pembentukan kepribadian individu, yaitu faktor dari dalam dirinya (internal) dan di luar dirinya (eksternal). Faktor internal adalah faktor yang berasal dari diri masing-masing individu. Faktor internal disebut juga faktor genetis yang merupakan bawaan sejak lahir, dan merupakan pengaruh heriditas (keturunan) dari salah satu sifat yang dimiliki oleh salah satu dari kedua orang tuanya. Atau bisa jadi berasal dari kombinasi sifat kedua orang tuanya. Juga dikatakan Osborne bahwa sifat-sifat anak telah ditentukan secara genetis. Faktor susunan genetis merupakan faktor pertama yang memengaruhi pembentukan kepribadian, yang akan memengaruhi sosok anak; pemalu atau agresif; dan sebagainya. Semua individu unik. ${ }^{5}$ Dapat dikatakan bahwa setiap orang memiliki kepribadian dasar yang telah dibentuk sejak dalam kandungan (genetis). Dari hari ke hari, kepribadiannya dibentuk oleh cara-cara yang kompleks. Walaupun kepribadian dapat berkembang atau berubah dari waktu ke waktu karena memang sifatnya dinamis. Namun tidak akan keluar dari sifat dasar atau bawaan (genetis) dari orang tuanya.

Perkembangan kepribadian seseorang tentunya tidak hanya dipengaruhi faktor internal saja. Tetapi juga dipengaruhi sejumlah faktor eksternal. Sedangkan faktor eksternal sebagaimana dijelaskan Sjarkawi, ialah faktor yang berasal dari luar individu

\footnotetext{
${ }^{2}$ Samsyu Yusuf dan Juntika Nurihsan, Teori Kepribadian (Bandung: PT. Remaja Rosdakarya, 2008), 74.

${ }^{3}$ Daviq Chairilsyah, ""Pembentukan Kepribadian Positif Anak Sejak Usia Dini”," EDUCHILD Vol.1, No.1 (2012): 1

${ }^{4}$ Daviq Chairilsyah, “"Pembentukan Kepribadian Positif Anak Sejak Usia Dini”, 1

${ }^{5}$ Cecil G. Osborne, Seni Bergaul (Jakarta: BPK Gunung Mulia, 2001), 142
} 
tersebut. Faktor eksternal ini biasanya merupakan pengaruh dari sosialnya mulai dari lingkungan terkecilnya, yaitu keluarga, teman, tetangga, sampai dengan pengaruh dari pelbagai media lainnya, seperti televisi, internet, film, atau media sosial cetak seperti koran, majalah, dan sebagainya. ${ }^{6}$

Dikatakan Stevanus, sebagai makhluk sosial, manusia senatiasa hidup dalam relasi dengan komunitas-komunitas, seperti keluarga, sekolah, gereja, dan lingkungan sosial lainnya. ${ }^{7}$ Kepribadian seseorang dipengaruhi oleh adanya proses sosialisasi. Oleh karena itu, tidak dapat dipungkiri bahwa kehidupan seseorang akan dipengaruhi oleh komunitas tersebut. Setiap komunitas pasti mewariskan pengalaman khas yang tidak diberikan komunitas lain.

Menurut Singgih, faktor eksternal yang pertama ialah latar belakang keluarga dan nilai-nilai sosio-budaya. Suatu tingkah laku yang ditampilkan oleh seseorang juga dipengaruhi oleh latar belakang keluarga serta lingkungan sosial budaya tempat ia berada. Artinya, apabila latar belakang keluarga serta nilai-nilai sosial budaya mendukung, maka seseorang akan mengembangkan kepribadian yang normal atau baik. Faktor eksternal yang kedua adalah latar belakang atau riwayat pendidikan, baik pendidikan formal maupun informal yang diperoleh invidu. Pada pendidikan baik yang formal maupun informal, diberikan stimulasi-stimulasi yang sistematis terhadap fungsi kognitif, psikomotor dan afektifnya, dalam upaya membentuk kepribadian yang menyeluruh. ${ }^{8}$

Faktor eksternal lain adalah pengalaman-pengalaman individu di dalam pergaulan atau sosialnya. Tak dapat disanggah, di dalam kehidupan sosialnya, seseorang senantiasa menjalani pergaulan dengan individu atau komunitas atau kelompok tertentu. Lingkungan sosial dapat berupa pergaulan sangat berpengaruh bagi para anggotanya. Setiap anggota dari komunitas atau kelompok-kelompok tersebut telah memiliki nilai, norma, kaidah, keyakinan tertentu yang dianut dalam keseharian. Nilai, norma atau keyakinan tersebut akan terefleksikan pada perilaku sehari-hari, baik sengaja atau pun tidak dalam pergaulan.

Faktor eksternal lain lagi yang turut memengaruhi pembentukan kepribadian seseorang, selain sosialnya, ialah pengalaman unik yang dialaminya, baik itu pengalaman yang manis maupun menyakitkan. Pengalaman unik dapat memengaruhi kepribadian seseorang. Kepribadian seseorang itu jelas berbeda-beda antara satu individu dengan individu lainnya karena pengalaman yang dialaminya. Setiap individu memiliki pengalaman-pengalaman unik, yang terjadi pada dirinya sendiri. Pengalaman

\footnotetext{
${ }^{6}$ Daviq Chairilsyah, “"Pembentukan Kepribadian Positif Anak Sejak Usia Dini”,.”, 5

${ }^{7}$ Kalis Stevanus, "Memaknai Kisah Orang Samaria Yang Murah Hati Menurut Lukas 10:25-37 Sebagai Upaya Pencegahan Konflik," BIA': Jurnal Teologi dan Pendidikan Kristen Kontekstual, 3, no. 1 (2020): 2.

${ }^{8}$ Singgih D. Gunarsa, Seri Psikologi: Psikologi Olahraga Prestasi (Jakarta: BPK Gunung Mulia, 2008), 
yang unik dimaksud di sini ialah kejadian atau peristiwa yang khusus dialami individu sendiri yang berbeda dengan yang lain.

Pengalaman hidup seseorang dalam komunitas sangat menentukan perkembangan kepribadiannya. Dan setiap individu mempunyai pengalaman hidup masing-masing. Pengalaman hidup tersebut akan membentuk sikap seseorang, baik negatif maupun positif terhadap kejadian atau peristiwa tersebut. Misalnya, jika seseorang mempunyai pengalaman mendapat perlakuan kekerasan baik verbal maupun non-verbal, fisik ataupun mental maka ada dua kemungkinan sikap yang muncul, yaitu sikap negatif maka ia akan ikut melakukan kekerasan dan balas dendam, atau sebaliknya sikap positif yakni tidak melakukan tindakan untuk balas melawan atau melakuakn tindak kekerasan kepada para pelaku. Sebaliknya, jikalau sikap yang diambil positif, maka ia akan tumbuh menjadi orang dengan kepribadian baik, tidak minder, tangguh, berempati, dan sebagainya. Dapat disimpulkan secara sederhana, kepribadian akan mengarahkan reaksi emosional dan rasional seseorang terhadap setiap pengalaman hidup.

Lebih jauh lagi dijelaskan Alwisol, faktor eksternal turut memengaruhi pembentukan kepribadian seseorang biasanya dengan dua (2) cara, yakni pertama, memberi standar untuk mengevaluasi perilaku. Faktor lingkungan berinteraksi dengan pengaruh-pengaruh pribadi, membentuk standar evaluasi diri individu. Melalui orang tua dan guru-guru, anak-anak belajar tentang hal baik atau buruk, perilaku yang dikehendaki dan yang tidak dikehendaki. Kedua, faktor eksternal memengaruhi regulasi diri dalam bentuk penguatan. ${ }^{9}$

Dari apa yang telah penulis kemukakan di atas, penulis menyimpulkan bahwa benarlah antara faktor pembawaan atau heriditas dan lingkungan sama-sama berperan penting dalam rangka pembentukan kepribadian seseorang. Kedua faktor tersebut yakni pembawaan (heriditas( dan lingkungan memiliki pengaruh yang sangat signifikan atau cukup besar dalam proses pembentukan kepribadian individu. Sebab memang manusia pada hakikatnya adalah makhluk yang perkembangannya dipengaruhi oleh pembawaan dan lingkungan. Sebab itu, pada dasarnya kepribadian seseorang adalah sebuah proses yang sangat panjang dimulai terbentuk sejak dari kandungan hingga proses kehidupan panjang berikutnya. Kepribadian seseorang yang nampak dari ucapan, sikap maupun perilaku tidak muncul begitu saja, tapi ada proses panjang dan juga ada faktor-faktor yang turut memengaruhinya. Proses pembentukan kepribadian terjadi melalui sosialisasi, di mana seorang individu berespon/bereaksi dan berinteraksi dengan individu lain di lingkuangan sosialnya, dan bagaimana meresponi suatu keadaan maupun kejadian atau peristiwa tertentu. Kepribadian seseorang cenderung baik atau buruk, dipengaruhi oleh berbagai faktor yang membentuknya dalam perjalanan hidupnya serta responnya menghadapi keadaan tersebut.

${ }^{9}$ Alwisol, Psikologi Kepribadian (Malang: Universitas Muhammadiyah Malang, 2018), 301 
Sebab itu, dapat dikatakan dalam bahasa lain, ada banyak faktor yang turut serta dalam pembentukan kepribadian individu. Dan salah satu faktor penting yang turut serta memengaruhi pembentukan kepribadian seseorang adalah melalui pengalaman hidup yang unik. Pengalaman unik bisa positif dan juga negatif. Di sini, penulis akan paparkan pengalaman unik Ayub dalam menyikapi penderitaannya.

Pembentukan kepribadian melalui pengalaman unik yang negatif, yaitu penderitaan sangat menarik perhatian penulis untuk menelitinya. Pengalaman unik tersebut memengaruhi kondisi emosional dan mental individu sehingga membentuk suatu kepribadian tertentu. Pengalaman-pengalaman hidup memberi pengaruh yang berbeda-beda pada tiap individu, dan pada alhirnya akan membentuk dalam dirinya suatu struktur kepribadian yang sifatnya tetap atau permanen.

Ayub merupakan salah satu tokoh yang cukup menonjol di Alkitab yang mengalami pembentukan kepribadiannya melalui pengalaman hidup yang unik bahkan ekstrim di dalam hidupnya, yaitu dimana ia mengalami penderitaan yang bertubi-tubi. Sebagaimana diungkapkan Stevanus, kisah Ayub di dalam kitab Ayub ini hingga sekarang pun masih bisa dikatakan tetap relevan menjadi kajian dan bahan diskusi ketika manusia mengalami musibah. Dengan jelas dikatakan Alkitab, Ayub adalah seorang yang beriman dan bukan orang fasik. Ayub seirang yang saleh, jujur, takut akan Tuhan dan menjahi kejahatan, tetapi faknya tidak luput atau dapat mengalami musibah yang begitu berat. ${ }^{10}$ Dengan demikian, nampak jelas bukan hanya faktor eksternal yang turut membentuk kepribadian Ayub. Tetapi juga faktor internal seperti iman kepada Allah. Yang menjadi pertanyaan, apakah Ayub masih memiliki kepribadian yang baik sebagaimana disebutkan di Alkitab sebelum penderitaannya, yaitu saleh, jujur, takut akan Allah serta menjauhi kejahatan setelah mengalami bertubi-tubi musibah? Apakah yang menjadikan Ayub tetap memiliki kepribadian yang baik meskipun menghadapi begitu banyak penderitaan, yaitu mengalami sakit penyakit sekujur tubuhnya, kehilangan harta bendanya, ditolak lingkungan dan para sahabatnya, bahkan kematian anak-anaknya?

Penulis tertarik untuk mendeskripsikan kepribadian tokoh Ayub yang sangat fenomenal dan menginspirasi serta menjadi model (prototype) dalam pengetrapan sikap yang tepat dalam situasi dan kondisi dalam kehidupan sehari-hari sebagai orang Kristen. Bagaimana Tuhan membentuknya dan bagaimana respons Ayub terhadap proses pembentukan dirinya melalui keadaan-keadaan yang tidak menyenangkan (baca: penderitaan) tersebut. Melalui kajian naratif kisah Ayub ini, diharapkan memiliki implementasi bagi kehidupan orang Kristen masa kini agar memiliki respons yang benar terhadap proses pembentukan Tuhan melalui keadaan-keadaan yang tidak

\footnotetext{
${ }^{10}$ Kalis Stevanus dan Stefanus M. Marbun, "Memaknai Kisah Ayub Sebagai Refleksi Iman Dalam Menghadapi Penderitaan," LOGIA: Jurnal Teologi Pentakosta, Vol. 1, No. 1 (2019): 23.
} 
menyenangkan sehingga menghasilkan sikap hidup dan karakter mulia serta iman yang kokoh dibangun atas dasar pengenalan pribadinya dengan Allah.

\section{Metode Penelitian}

Penelitian ini menggunakan pendekatan kajian biblikal tentang proses pembentukan kepribadian Ayub dengan metode tafsir naratif. Tafsir naratif merupakan suatu metode analisis Alkitab yang memfokuskan perhatian hanya pada teks dan tidak terlalu menaruh minat pada hal-hal yang berada di luar teks, misalnya aspek historis dari teks tersebut. ${ }^{11}$ Karena itu pendekatan naratif memberi perhatian khusus terhadap alur penokohan dan perspektif dari seorang narator.

Di sini penulis akan menarasikan kisah Ayub sebagaimana yang dinarasikan di dalam kitab Ayub sendiri mengenai pembentukan kepribadian Ayub. Untuk itu, penulis juga menggunakan kajian pustaka dengan memanfaatkan literatur baik berupa bukubuku, jurnal dan bacaan lain yang masih relevan dengan topik pembahasan dan disajikan secara deskriptif, yaitu bersifat menjelaskan, menuturkan masalah secara apa adanya.

\section{Hasil dan pembahasan}

Setelah melakukan penelitian keseluruhan kitab Ayub, selanjutnya penulis akan menyajikannya secara deskriptif mengenai identitas, keadaan pribadi dan sosial seorang Ayub serta pembentukan kepribadian Ayub dan kepribadiannya yang baik mulai dari awal penderitaannya hingga pasca penderitaannya.

\section{Identitas, Keadaan Pribadi dan Sosial Seorang Ayub}

Narator menceritakan Ayub sebagai pribadi yang saleh, jujur, takut akan Tuhan dan menjauhi kejahatan. Ayub adalah orang yang mengasihi, taat dan setia beribadah kepada Allah sebagaimana diceritakan narator di dalam pasal 1:1,8; 2:3. Selain itu, sang narator juga menuliskan identitas keluarga Ayub, yang memiliki satu istri dan dikarunia sepuluh (10), yaitu tujuh laki-laki dan tiga anak perempuan (1:2). Menurut Gannet, kata saleh memiliki pengertian adalah orang yang memiliki kehidupan rohani tidak bercela. ${ }^{12}$

Ditambahkan lagi oleh narator, bahwa Ayub adalah seorang yang sangat kaya raya di zamannya. Boleh dikatakan dalam istilah sekarang adalah sang konglomerat. Di dalam pasal 1 ayat 3 dicatat detail tentang harta milik Ayub. Ayun punya 7000 ekor kambing, 3000 ekor unta, 500 pasang lembu, 500 keledai betina dan budak-budak dalam jumlah yang sangat besar. Karena banyaknya harta jasmaninya, dikatakan bahwa Ayub seorang yang terkaya bahkan tiada yang lebih kaya daripada Ayub. Adalah sangat mungkin Ayub juga seorang yang terkenal atau sangat dikenal. Hal ini juga diungkapkan oleh Sukmana. Menurutnya, dalam konteks sosialnya di masyarakatnya, keadaan Ayub melukiskan bahwa ia seorang yang terpandang, termasyur, orang penting dan berkuasa. ${ }^{13}$

${ }^{11}$ Ibid, 49.

12 Alden A. Gannet, Pengertian Tentang Sakit Dan Penderitaan Dari Kitab Ayub (Jepara: Silas Press, n.d.), 2 .

${ }^{13}$ C. Iman Sukmana, "Penderitaan Ayub Dan Kekerasan Massa: Refleksi René Girard Dan Hannah Arendt," RESPONS, Vol. 14, no. 1 (2009): 101-123. 
Selain informasi tentang identitas diri Ayub, sanga narator kitab Ayub juga menceritakan anak-anak laki-laki Ayub memiliki suatu kebiasaan mengadakan pesta. Selain keterangan mengenai diri pribadi Ayub, narator juga mengisahkan anak-anak laki-laki Ayub yang memiliki kebiasaan berpesta (1:4). Diceritakan, setiap kali pesta berakhir, Ayub selalu memanggil mereka, dan melakukan tindakan memohon pengampunan kepada Tuhan. Ayub menguduskan anak-anaknya dengan mempersembahkan korban bakaran sebanyak anaknya. Ayub berpikir: "Mungkin anakanakku sudah berbuat dosa dan telah mengutuki Allah di dalam hati". Hal itu dilakukan Ayub senantiasa (1:5). Sekali lagi, di sini narator menyatakan kembali mengenai kepribadian Ayub, sebagai orang yang saleh, jujur, takut akan Tuhan serta menjauhi pribadi Ayub yang saleh dan takut akan Allah. Tindakan Ayub tersebut memberikan indikasi yang kuat mengenai kehidupan rohaninya yang tidak bercela. Menurut Atkinson, tindakan Ayub mempersembahkan korban bakaran kepada Allah karena ia tahu bahwa mengutuki Tuhan meruoakan tindakan dosa di hadapan-Nya. Itu sebabnya, Ayub ingin supaya selurh keluarganya tetap bersih dari dosa. ${ }^{14}$ Dengan bahasa lain, Ayub sangat menghormati Allah yang disembahnya. Ayub senantiasa berdoa kepada Tuhan bagi keluarganya dan berusaha menjaga kesucian keluarganya di hadapan-Nya. Semuanya itu menunjukkan kesadarannya akan Allah yang kuat. ${ }^{15}$

\section{Narasi Derita Ayub}

Kepribadian Ayub yang saleh, jujur, takut akan Tuhan dan menjauhi kejahatan adalah penekanan karakter atau moralitas maupun spiritualitas yang dinilai baik di hadapan-Nya, sehingga Ayub dibanggakan oleh Tuhan di depan iblis. Tidaklah berlebihan, bila dikatakan, tiada tokoh yang dicatat di Alkitab yang dibanggakan Tuhan di depan iblis, selain Ayub. Kualitas kepribadian inilah yang dipakai narator untuk mengemukakan kepribadian Ayub yang sebenarnya

Andar Ismail menyatakan bahwa yang menjadi pemicu penderitaan Ayub adalah kebanggaan Tuhan. Tuhan bangga melihat orang seperti Ayub. Lalu Tuhan menceritakan rasa bangga itu kepada Iblis. ${ }^{16}$

1:8 Lalu bertanyalah TUHAN kepada Iblis: "Apakah engkau memerhatikan hamba-Ku Ayub? Sebab tiada seorang pun di bumi seperti dia, yang demikian saleh dan jujur, yang takut akan Allah dan menjauhi kejahatan

Reaksi Iblis terhadap pernyataan Allah tentang Ayub sebagaimana diberitakan narator demikian:

1:9-10 Lalu jawab Iblis kepada TUHAN: "Apakah dengan tidak mendapat apa-apa Ayub takut akan Allah? Bukankah Engkau yang membuat pagar sekeliling dia dan rumahnya serta segala yang dimilikinya? Apa yang dikerjakannya telah Kauberkati dan apa yang dimilikinya makin bertambah di negeri itu.

1:11 tetapi ulurkanlah tangan-Mu dan jamahlah jamahlah segala yang dipunyainya, ia pasti mengutuki Engkau di hadapan-Mu."

\footnotetext{
${ }^{14}$ David Atkinson, Ayub (Jakarta: Yayasan Komunikasi Bina Kasih/OMF, 2002).aDavid Atkinson, Ayub (Jakarta: Yayasan Komunikasi Bina Kasih/OMF, 2002), 20-21

${ }^{15}$ Kalis Stevanus, "Kesadaran Akan Allah Melalui Penderitaan Berdasarkan Ayub 1-2," Dunamis: Jurnal Teologi dan Pendidikan Kristiani, Vol. 3, No. 2 (April 2019.): 121.

${ }^{16}$ Andar Ismail, Selamat Menabur (Jakarta: BPK Gunung Mulia, 1997), 32.
} 
Dari apa yang dikisahkan di dalam pasal 1:9-11, sebenarnya Iblis hendak mengatakan kepada Allah bahwa Ayub seorang yang saleh, jujur, takut akan Tuhan dan menjauhi kejahatan adalah maklum sebab dia menerima banyak kekayaan. Dalam bahasa lain, Ayub saleh supaya diberkati (kaya). Bila seandainya Tuhan tidak memberkati atau tidak menerima apa-apa, Iblis menduga bahwa Ayub akan mundur dari Tuhan, bahkan sangat mungkin akan mengutuki Tuhan.

Tetapi pendapat Iblis tentang Ayub ditentang Allah. Allah tidak sependapat. Menurut Allah, kekayaan bukan motivasi Ayub. Allah hendak menegaskan bahwa Ayub akan tetap konsisten menjadi pribadi yang saleh, jujur, takut akan Tuhan dan menjauhi kejahatan meskipun tidak menerima apapun dari Tuhan. Lalu TUHAN menantang ilblis untuk mencobai Ayub. Berfirmanlah TUHAN kepada Iblis: "Nah, segala yang dipunyainya ada dalam kuasamu; hanya janganlah engkau mengulurkan tanganmu atas dirinya. (1:12). Inilah awal mula derita Ayub. Iblis menjatuhkan sederatan musibah kepada Ayub dan keluarganya (1:13-19; 2:7-8).

Pendapat Andar Ismail juga didukung oleh Tolanda, bahwa derita Ayub diawali dari sebuah pertanyaan dan pernyataan yang diucapkan Tuhan kepada Iblis tentang kepribadian Ayub yang baik. Menurut Tolanda, pujian atau kebanggaan yang diucapkan Tuhan tentang pribadi Ayub merupakan latar belakang penderitaan yang menimpanya di kemudian hari. Pujian atau pernyataan kekaguman Tuhan tersebut ternyata telah membangkitkan rasa cemburu Iblis terhadap Ayub, sehingga hal itu mendorong Iblis meminta izin kepada-Nya untuk mencobainya. ${ }^{17}$

Narator dalam prolognya menyebutkan bahwa derita Ayub adalah adanya intervensi Iblis yang cemburu terhadap Ayub, karena Ayub dipuji dan dibanggakan oleh Tuhan di depan para malaikat-Nya, termasuk di depan Iblis. Kecemburuanlah yang mendorong iblis untuk mencobai Ayub guna membuktikan bahwa kesalehan Ayub kepada Tuhan adalah kesalehan yang pamrih karena Ayub diberkati harta melimpah. Atas ijin Tuhan, iblis menghancurkan semua harta miliknya, membunuh semua anaknya, bahkan dirinya sendiri tertimpa penyakit yang menjijikan (1:6-20; 2:1-8). ${ }^{18}$

Pendapat berbeda dikemukakan oleh Rene Girard bahwa sebenarnya isu utama penderitaan Ayub bukanlah ulah iblis, tapi Ayub adalah korban dari masyarakatnya. Menurut Girard, Ayub sendiri dengan jelas mengucapkan penyebab dari penderitannya ialah karena ia disingkirkan dan di bully oleh orang-orang di sekitarnya. Dimana setiap orang berpaling dari Ayub dan yang ada di hadapannya adalah maut. Diandaskan Girard, sebenarnya Ayub merupakan korban yang menjadi kambing hitam dari masyarakatnya. Ayub sendiri mengatakan sebab penderitannya di pasal 19:13-19.19

Saudara-saudarku dijauhkan-Nya dari padaku,

Dan kenalan-kenalanku tidak lagi mengenal aku.

Kaum kerabatku menghindar, dan kawan-kawanku melupakan aku.

\footnotetext{
${ }^{17}$ Irvin Tolanda, "Kedaulatan Allah Atas Iblis Berdasarkan Kitab Ayub Pasal 1 Dan 2 Serta Relevansinya Dalam Kehidupan Orang Percaya," Jaffray, Vol.9, No.2 (2011): 53-89.

${ }^{18}$ Kalis Stevanus, “Analisis Pertanyaan Retorika Dalam Ayub 40:1-28,” Dunamis: Jurnal Teologi dan Pendidikan Kristiani, Vol. 2, No.2 (April 2018): 120.

${ }^{19}$ René Girard, Ayub Korban Masyarakatnya (Penerj. Daniel K. Listijabudi), 1st ed. (Jakarta: BPK Gunung Mulia, 2003), 4-5.
} 

dikenal,

Anak semang dan budak perempuanku menganggap aku orang yang tidak aku dipandang mereka orang asing.

Kalau aku memanggil budakku, ia tidak menyahut;

aku harus membujuknya dengan kata-kata manis.

Nafasku menimbulkan rasa jijik kepada isteriku, dan bauku memualkan saudara-saudara sekandungku.

Bahkan kanak-kanakpun menghina aku, kalau aku berdiri, mereka mengejek aku.

Semua teman karibku merasa muak terhadap aku;

Dan mereka yang kukasihi, berbalik melawan aku.

Pendapat serupa dengan Girard juga dikemukakan oleh Singgih bahwa penderitaan Ayub terjadi karena ketidakadilan yang dilakukan oleh orang lain di masyarakatnya. ${ }^{20}$

\section{Narasi Kepribadian Ayub}

Di sini penulis memaparkan beberapa kepribadian Ayub yang tampak menyolok baik sebelum menderita maupun sesudahnya. Berdasarkan temuan, berikut adalah karakteristik kepribadian Ayub sebagaimana diceritakan narator kitab ini.

Seorang yang saleh, jujur, takut akan Tuhan dan menjauhi kejahatan $(1: 1,8 ; 2: 3)$

Narator memperkenalkan tokoh Ayub sebagai seorang yang berasal dari tanah Us, yaitu seorang yang saleh, jujur, takut akan Tuhan dan menjauhi kejahatan. Ditambahkan olen narator keterangan yang sangat penting dan ditulis berulang-ulang mengenai tokoh ini adalah kepribadiannya yang baik dan luhur. Narator tidak satu kalipun mencatat adanya keburukan karakternya atau moralitasnya sebagaimana tercatat di dalam pasal 1:1 oleh narator dan 2 kali diucapkan oleh Tuhan sendiri (1:8; $2: 3)$.

Takut akan Tuhan dan menjauhi kejahatan telah menjadi landasan kesalehan dan kejujuran Ayub. Kesalehan adalah mengacu kepada integritas moral Ayub di hadapan Tuhan. Sedangkan jujur menunjukkan kesesuaian dalam pikiran, perkataan, dan perbuatan. Dengan kata lain, tidak ada kontra antara apa yang di hati dengan perkataan dan tingkah laku dalam kesehariannya.

Di sisi lain, narator menceritakan pengetrapan kesalehan atau kehidupan keberimanan Ayub di dalam keluarganya. Hal ini dicatat di pasal 1:4-5 di mana Ayub senantiasa menguduskan seluruh keluarganya dengan mempersembahkan korban bakaran sebanyak jumlah anaknya. Ayub takut kalau anak-anaknya telah melakukan dosa dan telah mengutuki Allah di dalam hati mereka. Hal itu ditegaskan narator, Ayub melakukannya senantiasa. Jelas ini cerminan dari keberimanan da kesalehan Ayuh di hadapan Tuhan.

Rumbi menyatakan bahwa Ayub berperan sebagai perantara atau imam bagi keluarganya. Di mana imam bertindak sebagai perantara memohonkan pengampunan

\footnotetext{
${ }^{20}$ E. G. Singgih, Kitab Ayub Sebagai Kritik Terhadap Konseling Pastoral. Dalam Emanuel Gerrit Singgih (Ed.), Dua Konteks: Tafsir-Tafsir Perjanjian Lama Sebagai Respons Atas Perjalanan Reformasi Di Indonesia (Jakarta: PT BPK Gunung Mulia., 2009), 201.
} 
kepada Tuhan atas umat-Nya yang berdosa. Karena itu, seorang imam harus menjaga kekudusan di hadapan Tuhan sebab itu menjadi kunci relasi dengan-Nya. ${ }^{21}$

Ayub melakukan tugas ke-imam-an bagi keluarganya. Ayub merupakan orang yang taat dan setia melakukan tugas atau perannya sebagai iman di dalam keluarganya. Sebagai orang tua, Ayub sangat memerhatikan kekudusan dan kehidupan rohani keluarganya. Demikianlah dilakukan Ayub senantiasa.

\section{Seorang yang Tulus atau Berintegritas (1:22; 2:3)}

Ayub menempuh jalan kehidupan yang saleh, jujur, takut akan Tuhan dan menjauhi kejahatan. Dapat dikatakan secara karakter-moralitas, Ayub tidak bercela baik di hadapan manusia dan Allah.

Ayub tetap memegang erat integritasnya (Ayub 2:3) Meskipun mendadak semua yang dimilikinya lenyap, baik harta benda, budak, bahkan anak-anaknya mati. Kemudian Ayub ditimpa penyakit kulit di seluruh tubuhnya. Sang narator mencatat bahwa dalam kesemuanya itu Ayub tetap tidak berbuat dosa. Ini penting, sehingga narator menuliskan dua kali pada pasal 1:22 dan pasal 2:3.

Narator juga menyatakan bahwa Ayub seorang pribadi yang tulus (berintegritas) dalam seluruh aspek kehidupannya. Moralitas sangat terpuji di sosialnya pada zamannya. Ayub tetap mempertahankan integritasnya meskipun dalam keadaan yang sulit, menghadapi tentangan dari kelompok sosialnya yang diwakili oleh ketiga (3) sabahatnya, yaitu Elifas, Bildab, dan Zofar (1:11).

Kemudian Iblis bereaksi merespon pernyataan Tuhan dengan mempertanyakan integritas Ayub. Penilaian Tuhan terhadap kepribadian Ayub disanggah Iblis. Karena Iblis menantang Tuhan untuk mengambil kembali segala berkat yang telah diberikan kepadanya. Iblis hendak mengatakan kepada Tuhan, bahwa Ayub pasti akan undur daripada-Nya dan berbalik mengutuki-Nya. Akhirnya, Tuhan menerima tantangan iblis tersebut dengan memberi izin kepadanya untuk mencobai Ayub. Namun, pada akhirnya, terbukti bahwa Ayub adalah seorang yang tulus dalam melayani Allah. Ayub tidak mengerti alasan di balik penderitaannya, namun dia tetap memegang integritasnya dan keloyalan kepada Allah. Ayub tidak menyangkal Allah, apalagi mengutuki Allah sebagaimana yang diduga oleh Iblis $(1: 11 ; 2: 5)$ maupun bujukan istrinya (2:9).

Pada pasal 27:6, Ayub mengatakan: "Kebenaranku kupegang teguh dan tidak kulepaskan...". Nampak jelas, narator dengan gamblang menunjukkan bahswa Ayub seorang laki-laki berpegang pada integritasnya (2:3). Meskipun Ayub tetap tidak memahami alasan penderitaannya, ia tidak goyah dalam kesetiaan itu. Ayub tetap mempertahankan kehidupannya yang bersih dan menjadikan Allah sandarannya hidupnya, sehingga ditegaskan Ayub bahwa sampai mati pun tetap menyatakan dirinya tidak melakukan dosa atau tidak bersalah di hadapan-Nya. Dengan kata lain, Ayub tidak ada menyingkirkan integritas dari kehidupannya (27:5-6).

\section{Seorang yang Optimis}

Ayub adalah orang yang memiliki optimisme kuat. Tanpa optimisme yang kuat seseorang akan berakhir dengan hilangnya semangat. Ayub tidak membiarkan dirinya

\footnotetext{
${ }^{21}$ Frans Paillin Rumbi, "Babak Akhir Penderitaan, Dosa Dan Teodice Dalam Epilog Kitab Ayub 42:7-17," Veritas Lux Mea (Jurnal Teologi dan Pendidikan Kristen) Vol.1, No.2 (2019): 53-64.
} 
dihipnotisir oleh penderitaan fisiknya, kehilangan harta bendanya serta anak-anaknya. Juga sikap tidak empatik dari teman-temannya tidak mengurangi sikap optimisme Ayub kepada Allah. Ayub optimisme karena segala hal yang terjadi itu ada segi kebaikannya.

Meskipun Ayub pernah menjadi kecil hati, dengan mengatakan orang fasik tanpak jauh lebih baik keadannya daripadanya (21:7-9). Bahkan Ayub sempat menyatakan dirinya ingin mati saja. "Oh, sekiranya di Syeol kausembunyikan aku, sekiranya engkau merahasiakan aku sampai kemarahanmu surut!" serunya (14:13). Dalam semuanya itu, Ayub menjadikan takut akan Allah menjadi pegangan hidupnya. Dan itu diakui oleh para penentangnya,"Bukankah takutmu akan Allah yang menjadi sandaranmu, dan kesalehan hidupmu menjadi pengharapanmu" (4:6).

\section{Seorang yang bermurah hati}

Kemurahan hati Ayub dikisahkan narator di dalam pasal 29:11-13,16 demikian: Apabila telinga mendengar tentang aku, maka aku disebut berbahagia;

Dan apabila mata melihat, maka aku dipuji.

Karena aku menyelamatkan orang sengsara yang berteriak minta tolong, Juga anak piatu yang tiada penolongnya;

Aku mendapat ucapan berkat dari orang yang nyaris binasa, dan hati seorang janda kubuat bersukaria.

Aku menjadi bapa bagi orang miskin,

Dan perkara orang yang tidak kukenal, kuselidiki. .

Sungguh, Ayub seorang yang kaya raya tapi juga berjiwa murah hati atau dermawan terhadap sesama yang membutuhkan bantuan, yang kekurangan tanpa membeda-bedakan status sosialnya. Sikap dermawan adalah ajaran Kristus sebagaimana dikatakan di Lukas 6:36,"Hendaklah kamu murah hati, sama seperti Bapamu adalah murah hati." Bermurah hati adalah amanat Tuhan bagi setiap orang percaya. Karena itu, bermurah hati semestinya menjadi spirit atau karakter yang dimiliki oeh orang percaya sebagaimana Bapa adalah murah hati. Bukankah setiap orang percaya telah beroleh kemurahan dari Tuhan. Kepribadian yang baik, ditandai dengan sikap yang penuh belas kasihan terhadap orang lain—suka menolong, tidak kikir dan baik hati.

\section{Seorang yang setia pada istrinya}

Berita mengenai istri Ayub dapat dijumpai pertama kali pada pasal 2:9, maka berkatalah isterinya kepada Ayub: masih bertekunkah engkau dalam kesalehanmu? Bahkan istrinya mengatakan kepadanya: kutukilah Allahmu dan matilah. Ayat ini ditempatkan pada bagian kedua dari penderitaan Ayub. Bagian pertama penderitaan Ayub diceritakan pada pasal 1:6-22 yang diawali dengan kalimat: "Pada suatu hari datanglah anak-anak Allah menghadap TUHAN dan di antara mereka datanglah juga Iblis" (1:6). Dan bagian kedua penderitaan Ayub diceritakan pada pasal 2:1-13 yang juga diawali dengan kalimat yang sama dengan pasal 1:6, demikian: "Pada suatu hari datanglah anak-anak Allah menghadap TUHAN dan di antara mereka datang juga Iblis untuk menghadap TUHAN" (2:1).

Pada penderitaan pertama, Ayub telah kehilangan seluruh harta bendanya, kematian para pegawainya serta anak-anaknya. Sedangkan pada penderitaan kedua, 
narator hanya menuliskan keadaan Ayub yang sangat menderita penyakit kulit yang menjijikan dari telapak kakinya sampai kepalanya (2:7). Pada bagian kedua dari penderitaannya ini diberitakan, bahwa "Ayub mengambil sekeping beling untuk menggaruk-garuk badannya, sambil duduk di tengah-tengah abu" (2:8).

Pada bagian pertama penderitaan Ayub, tidak nampak peran isteri Ayub di dalamnya. Istri Ayub muncul di bagian kedua dari penderitaannya (2:9). Melihat kondisi Ayub yang sangat mengerikan dan memilukan ini, berkatalah istri Ayub kepada Ayub mengajak mengutuki Tuhan (2:9). Sangat keras perkataan istri Ayub ketika melihat penderitaan Ayub yang begitu berat dengan ajakan untuk "mengutuki" Allah serta ajakan untuk meninggalkan imannya atau keloyalannya kepada Allah.

Bagaimana reaksi Ayub menanggapi pernyataan keras istrinya tersebut? Di dalam pasal 2:10 dikatakan, "Tetapi jawab Ayub kepadanya: 'Engkau berbicara seperti perempuan gila! Apakah kita mau menerima yang baik dari Allah, tetapi tidak mau menerima yang buruk?" Sangat nampak bahwa Ayub tidak pernah menolak keberadaan istrinya. Artinya Ayub tetap setia pada istrinya. Sebaliknya justru menguatkan istrinya agar menerima pencobaan tersebut dan percaya, setia kepada Tuhan. Ayub mengajak istrinya untuk selalu memuji Tuhan di dalam menjalani penderitaan yang demikian berat ini sebagaimana diberitakan narator pada pasal 1:20 dengan berkata:" terpujilah nama TUHAN!"

Ayub jujur mengenai keberadaan dirinya di depan istrinya pada pasal 19:17, Ayub mengungkapkan demikian: "Nafasku menimbulkan rasa jijik kepada isteriku, ..." Sampai di sini Ayub tetap menunjukkan kesetiaan pada istrinya. Ayub memiliki komitmen yang tinggi terhadap pernikahan. Ayub tetap setia pada istrinya, seperti diungkapkan pada pasal 31:1,9,11.

"Aku telah menetapkan syarat bagi mataku, masakan aku memperhatikan anak dara?

Jikalau hatiku tertarik kepada perempuan, dan aku menghadang di pintu sesamaku, Karena hal itu adalah perbuatan mesum,

bahkan kejahatan, yang patut dihukum oleh hakim.

Memang pada pasal terakhir (42) ketika keadaan Ayub telah dipulihkan Tuhan bahkan diberkati dua kali lipat jumlahnya dari segala kepunyaannya dahulu, sang narator tidak menuliskan lagi peran atau keberadaan istri Ayub. Di mana istri Ayub. Dari mana Ayub mendapatkan anak-anak lagi: tujuh orang anak laki-laki dan tiga orang anak perempuan (42:13), apakah dari istri pertamanya atau dari istri yang lain? Alkitab diam.

Di sini nampaknya narator hendak memberi pesan bagi pembacanya, seperti Ayub yang tetap setia kepada Tuhan meskipun berhadapan dengan penderitaan, termasuk disalahpahami oleh pasanganya, maka demikian juga pembaca kitab Ayub diharapkan setia kepada Tuhan (tentunya juga terhadap istrinya) sekalipun diperhadapkan dengan pelbagai tantangan dan penderitaan.

\section{Kesimpulan}

Pada dasarnya musibah dapat dialami oleh siapa saja tanpa memandang status dan keadaan sosial, moralitas maupun spiritualitasnya. Ayub adalah contoh nyata dari kisah seseorang yang mengalami pelbagai musibah meskipun memiliki kepribadian 
yang baik. Kepribadian Ayub dibentuk oleh faktor eksternal dan internal. Sangat jelas sang narator kitab Ayub mengungkapkan bahwa kepribadian Ayub, baik sebelum maupun pasca penderitaannya, ia tetap memiliki kepribadian yang baik. Segala penderitaan yang dialaminya tidak merubah atau mengoyakkan kepribadian Ayub yang baik. Kepribadian Ayub sebagaimana dikisahkan di dalam Kitab Ayub adalah: pertama, ia adalah seorang yang saleh dan jujur; takut akan Allah dan menjauhi kejahatan. Kedua, ia adalah seorang yang tulus atau berintegritas. Ayub tetap setia kepada Allah dan melayani-Nya dengan ketulusannya tanpa pamrih. Ketiga, ia adalah seorang yang optimis. Iman kepada Allah menjadi tempat sandarannya sehingga ia mampu menerima penderitaannya. Keempat, ia adalah seorang yang murah hati. Ia seorang yang peka dan empati terhadap keadaan orang lain di sekitarnya. Terakhir, ia adalah seorang yang setia pada istrinya.

\section{Daftar Pustaka}

Alden A. Gannet. Pengertian Tentang Sakit Dan Penderitaan Dari Kitab Ayub. Jepara: Silas Press, n.d.

Alwisol. Psikologi Kepribadian. Malang: Universitas Muhammadiyah Malang, 2018.

Cecil G. Osborne. Seni Bergaul. Jakarta: BPK Gunung Mulia, 2001.

David Atkinson. Ayub. Jakarta: Yayasan Komunikasi Bina Kasih/OMF, 2002.

Daviq Chairilsyah. ""Pembentukan Kepribadian Positif Anak Sejak Usia Dini",." EDUCHILD Vol.1, No.1 (2012)

Ismail, Andar. Selamat Menabur. Jakarta: BPK Gunung Mulia, 1997.

Jalaludin. Teologi Pendidikan, (Jakarta: Jakarta: PT Raja Grafindo Persada, 2003.

Kalis Stevanus. “Analisis Pertanyaan Retorika Dalam Ayub 40:1-28." Dunamis: Jurnal Teologi dan Pendidikan Kristiani Vol. 2, No.2 (2018)

- - - "Kesadaran Akan Allah Melalui Penderitaan Berdasarkan Ayub 1-2." Dunamis: Jurnal Teologi dan Pendidikan Kristiani 3, no. 2 (2019)

_-_. "Memaknai Kisah Orang Samaria Yang Murah Hati Menurut Lukas 10:25-37 Sebagai Upaya Pencegahan Konflik." BIA': Jurnal Teologi dan Pendidikan Kristen Kontekstual, Vol. 3, no. 1 (2020)

Kalis Stevanus dan Stefanus M. Marbun. "Memaknai Kisah Ayub Sebagai Refleksi Iman Dalam Menghadapi Penderitaan.” LOGIA: Jurnal Teologi Pentakosta, Vol. 1, No. 1 (2019)

Koentjaningrat. Pengantar Ilmu Antropologi. Jakarta: Rineka Cipta, 1990.

René Girard. Ayub Korban Masyarakatnya (Penerj. Daniel K. Listijabudi),. 1st ed. Jakarta: BPK Gunung Mulia, 2003. 
Rumbi, Frans Paillin. "Babak Akhir Penderitaan, Dosa Dan Teodice Dalam Epilog Kitab Ayub 42:7-17." Veritas Lux Mea (Jurnal Teologi dan Pendidikan Kristen), Vol.1, No.2 (2019)

Samsyu Yusuf dan Juntika Nurihsan. Teori Kepribadian. Bandung: PT. Remaja Rosdakarya, 2008.

Singgih D. Gunarsa. Seri Psikologi: Psikologi Olahraga Prestasi. Jakarta: BPK Gunung Mulia, 2008.

Singgih, E. G. Kitab Ayub Sebagai Kritik Terhadap Konseling Pastoral. Dalam Emanuel Gerrit Singgih (Ed.), Dua Konteks: Tafsir-Tafsir Perjanjian Lama Sebagai Respons Atas Perjalanan Reformasi Di Indonesia. Jakarta: PT BPK Gunung Mulia., 2009.

Sukmana, C. Iman. "Penderitaan Ayub Dan Kekerasan Massa: Refleksi René Girard Dan Hannah Arendt." RESPONS, Vol. 14, No. 1 (2009)

Tolanda, Irvin. "KEDAULATAN ALLAH ATAS IBLIS BERDASARKAN KITAB AYUB PASAL 1 DAN 2 SERTA RELEVANSINYA DALAM KEHIDUPAN ORANG PERCAYA.” Jaffray Vol.9, No.2 (2011)

Uswah Wardiana. Psikologi Umum. Jakarta: PT Bina Ilmu, 2004. 